\title{
Çocuk Edebiyatında “Şiddet Dili”” Farkındalık Ölçeği: Geçerlik ve Güvenirlik Çalışması
}

\section{Lokman TURAN 1}

Fatma GEREZ TAŞGIN 2

APA: Turan, L.; Gerez Taşgın, F. (2018). Çocuk Edebiyatında "Şiddet Dili” Farkındalık Ölçeği: Geçerlik ve Güvenirlik Çalışması. RumeliDE Dil ve Edebiyat Araştırmaları Dergisi, (12), 232-248. DOI: $10.29000 /$ rumelide. 472767

\section{$\ddot{O} \mathbf{z}$}

\begin{abstract}
Bu araştırmanın amacı, çocuk edebiyatında şiddet dili farkındalık ölçeğinin geçerlik ve güvenirlik çalışmasının yapılmasıdır. Çocuk edebiyatında şiddet dili farkındalık ölçeğinin geçerlik ve güvenirlik çalışması bir devlet üniversitesinin eğitim fakültesinin, okul öncesi eğitimi, sınıf eğitimi ve Türkçe eğitimi ana bilim dallarında öğrenim görmekte olan toplam 413 öğretmen adayından oluşan üç ayrı çalışma grubundan elde edilen veriler üzerinden yapılmıştır. Çalışma gruplarının belirlenmesinde "Çocuk Edebiyatı" dersinin alınmış olmasına dikkat edilmiştir. Araştırmada ölçeğin kapsam ve görünüş geçerliği için uzman görüşüne başvurulmuştur. Ölçeğin yapı geçerliğini sağlamak amacıyla yapılan açımlayıcı faktör analizi sonucunda 17 maddeden oluşan 2 faktörlü bir yapı elde edilmiştir. 13 maddeden oluşan 1. faktöre ilişkin maddeler incelendiğinde, bu maddeler "içerik" boyutu olarak 4 maddeden oluşan 2. faktöre ilişkin maddeler incelendiğinde de "etki" boyutu olarak adlandırılmıştır. Elde edilen bu yapının örneklem verisine iyi uyum gösterip göstermediğini anlamak amacıyla yapılan doğrulayıcı faktör analizi sonuçları ise ölçeğin uygulandığı örnekleme uyumunun kabul edilebilir düzeyde olduğunu göstermiştir $\left(\chi^{2} / \mathrm{df}=1,548 ; \mathrm{df}=118, \mathrm{p}=0.00 ; \mathrm{RMSEA}=0,055 ; \mathrm{SRMR}=0,054\right.$; AGFI=.90; TLI=.91; CFI=.93; GFI=.90). Ölçeğin iç tutarlllık güvenirlik katsayısı ölçeğin tamamı için .88 olarak bulunmuştur. Bu sonuçlar geliştirilen ölçeğin geçerli ve güvenilir bir araç olduğunu göstermektedir. Ölçek yardımıyla çocuk edebiyatı alanında çalışan araştırmacılar, öğretmen adaylarının çocuk edebiyatında şiddet dili farkındalıklarını belirleyebilecektir. Ayrıca ölçeğin çocuk edebiyatına yönelik öğrenme-öğretme etkinliklerinin düzenlenebilmesinde araştırmacılara yardımcı olacağı düşünülmektedir.
\end{abstract}

Anahtar kelimeler: Çocuk edebiyatı, şiddet dili, ölçek geliştirme, geçerlik, güvenirlik.

\section{“Violence Language" Awareness Scale in Children's Literature: Validity and Reliability Study}

\begin{abstract}
The aim of this study is to study the validity and reliability of the violence language awareness scale in children's literature. This study was carried out on the data obtained from 413 students and three seperate groups of candidate teachers who were studying in the departments of preschool education, classroom education and Turkish education of a state university education faculty. Attention was paid
\end{abstract}

\footnotetext{
1 Prof. Dr., Atatürk Üniversitesi, Kazım Karabekir Eğitim Fakültesi, Türkçe Eğitimi, lokmanturan@gmail.com, ORCID ID: oooo-0002-8622-7753 [Makale kaylt tarihi: 3.7.2018-kabul tarihi: 15.8.2018]

2 Doktora Öğrencisi, Atatürk Üniversitesi, Eğitim Bilimleri Enstitüsü, Türkçe Eğitimi ABD, fatmagereztasgin.90@gmail.com, ORCID ID: 0000-0001-5960-0658 


\begin{abstract}
to the fact that the "children literature" lesson has been taken in determining the study group. Expert opinion was taken for the content and face validity. As a result of exploratory factor analysis made to ensure the structure validity of the scale, 2 factor structure consisting of 17 items was obtained. When the examine the items of the 1st factor consisting of 13 items, these items were called as "content" dimension and the 2nd factor consisting of 4 items were called as "effect" dimension. The results of the confirmatory factor analysis to determine whether the obtained structure is well adapted to the sample data showed that the sampling fit of the scale is acceptable $\left(\chi^{2} / \mathrm{df}=1,548 ; \mathrm{df}=118, \mathrm{p}=0.00\right.$; RMSEA=0,055; SRMR=0,054; AGFI=.90; TLI=.91; CFI=.93; GFI=.90). The internal consistency coefficient for the entire scale was found to be .88 . These results show that the developed scale is a valid and reliable tool. When the help of the scale researchers working in the field of childrens literature will be able to determine the candidate teachers' awaraness of violence in children literature. It is also beleived that the survey will help the researchers in arragement of learningteaching activities for childrens' literature.
\end{abstract}

Key words: Children's literature, violence language, scale development, validity, reliability.

\title{
1. Giriş
}

Çocuk, o-15 yaş grubunu içine alan (Şahin, 2015) bebeklik çağı ile ergenlik çağı arasındaki dönemde bulunan insan (Oğuzkan, 2010) olarak tanımlanmaktadır. Çocuk edebiyatı (yazını) ise, erken çocukluk döneminden başlayıp ergenlik dönemini içine alan, çocukların dil gelișimi ve anlama seviyelerine uygun olarak, duygu ve düşünce dünyalarını sanatsal niteliği olan iletilerle besleyen, beğeni seviyelerini yükseltmeyi hedefleyen ürünlerin genel adı (Sever, 2003, s. 9) olup gelişme çağındaki çocukların duygu ve düşünce dünyası ile anlama ve kavrama becerilerine hitap eden edebiyat türüdür (Şimşek, 2014, s.15). Oğuzkan (210, s. 3)'a göre, çocuk edebiyatı çocukluk çağındakilerin duygu ve düşüncelerine hitap eden yazılı ve sözlü eserleri kapsar. Şirin (2007, s. 16)'e göre ise, çocuk edebiyatı, temel kaynağı çocuk ve çocukluk olan, çocuğun algı, ilgi, dikkat, düşünce ve hayâl dünyasına göre hazırlanan; çocuk gerçeğini ortaya koyan; dilsel, düşünsel olarak ve tiplerin sunumunda çocuğa göre içeriği sade bir biçimde ve samimiyetle işleyen; çocuğa okuma alışkanlığı kazandırmasının yanı sıra çocuğun sanatsal yönden de gelişmesine katkı sağlayan, çocuğu duyarlı ve bilinçli bir şekilde yetişkinliğe hazırlayan bir edebiyattır.

Çocuk edebiyatı genel edebiyata göre daha yeni bir alan olmasına karşın, ülkemizde yaklaşı 160 yıldır, Batı coğrafyasında ise 300 yıldır varlığını sürdürmektedir (Neydim, 2014, s.294). Ancak çocuk edebiyatının şekillenmesi ve bu alanın genel hatlarının ortaya konması zaman alır. Çocukluk döneminin kısa bir zamanı kapsaması, çocukların beklenti ve ihtiyaçlarının hızlı bir şekilde değişmesi, edebiyatçıları sürekli bir yenilenmeye sevk eder. Çocuk gerçekliğini çocuk bakışıyla ele alan çocuk edebiyatı eserinin kahramanı genellikle çocuktur. Öznesi çocuk olan edebiyatta çocuğa görelik ilkesi göz ardı edilmişse böyle bir eseri, çocuk edebiyatı bağlamında değerlendiremeyiz (Şirin, 2007, s.34).

Çocuk edebiyatı dersinin asıl amacı, geleceğin öğretmenlerine, çocuk kitaplarının ne anlam ifade ettiğini ve nitelikli bir çocuk kitabının fiziksel ve içerik özelliklerini ayrıntılarıyla öğretmektir. Bu dersi alan öğrencilerin yıl sonunda nitelikli bir çocuk kitabının nasıl olması gerektiğini kuramsal ve uygulamalı olarak öğrenmiş olması gerekir (Temizyürek, 2014, s. 301).

Çocuk edebiyatı eserlerinin çocuğun fiziksel ve psikososyal gelişimine uygun olması, bu edebiyat çerçevesinde "çocuğa görelik" ilkesini akla getirmektedir. Çocuğa görelik ilkesinde çocuğun duyguları, düşünceleri, ihtiyaç ve ilgileri esastır. Dursunoğlu (2015, s. 32)'na göre “çocuğa görelik” ilkesi 
dendiğinde; çocuğun hayal gücüne hitap eden, kolayca okuyup anlayabileceği anlatım gücüne sahip, çocuğu duygu ve düşünce yönünden besleyen ve işledikleri konu itibariyle çocuğun ilgisini çeken metinler akla gelmektedir. Çocuğa görelik ilkesinin varlığı ise çocuk edebiyatının dayanması gereken bazı özellikleri de beraberinde getirmektedir. Çocuk edebiyatı ürünlerinde bulunması gereken ilkeleri Sever (2003, ss. 191-192) aşağıdaki gibi sıralamıştır:

-Çocuğun içtenliği ve anlatımın doğallığı bir arada olmalıdır.

- Yazar çocuklarla arkadaşlık kurabilmelidir.

-Kitaplar çocuklara kaldıramayacağı sorumluluklar yüklememelidir.

•Kitaplarda Türkçe'mizin zengin anlatım olanakları sezdirilmeli ve çocukların kavramsal gelişimine katkı sağlamalıdır.

-Kahramanların fiziksel özellikleri ile metinde aktarılan kişilik özellikleri uyum içinde olmalıdır.

•Kitaplar çocukları hem sanatsal hem de düşünsel açıdan geliştirecek nitelikte olmalıdır.

-Kitaplar çocuğu yaşama hazırlamalı, çocuğun kendini gerçekleştirmesine olanak tanımalıdır.

-Yazarın anlattıkları, çocuğu yaşam-anlam gerçeğinden koparmamalıdır.

-Kitaplar çocukları okumaya heveslendirecek bir tasarıma sahip olmalı ve çocuğa özenle sunulmalıdır.

- Çocuklara dilin imkânlarıyla oluşturulmuş yeni yaşantılar sunma görevi çocuk edebiyatına ait olmakla birlikte sunulan yaşantılardan çıkarım yapma sorumluluğu çocuğa bırakılmalıdır.

Çocuk edebiyatının temel niteliklerinin ortaya konması ve çocuğa görelik ilkesi, çocuk edebiyatı eserlerinin nasıl olması gerektiği konusunda bir çerçeve oluşturmaktadır. Eserler bu bilgilerin ve niteliklerin ışığında eleştiri süzgecinden geçirildiğinde nitelikli eserlerin sayıca artabileceği de düşünülebilir. Çocuk edebiyatına yönelik eleştirilerin edebiyat ürünlerinin niteliğine göre özenle belirlenmesi gerekir. Çocuk edebiyatı eleştirisinde edebiyat kuramlarından yararlanılırken, sosyolojik ve psikolojik verilerin de dikkate alınması gerekir. Çocuk edebiyatının temel hedef kitlesi çocuk olduğundan, bu edebiyata yönelik eleştirilerde okurun beklentileri göz ardı edilmemelidir. Çocuk edebiyatı metinleri araştırma/eleştirmeye tabi tutulurken hangi yaş grubuna hitap ettiği gözden kaçırılmamalıdır. Dolayısıyla çocuk edebiyatı ürünlerini eleştiren/inceleyen araştırmacı çocukluk felsefesini, sosyolojisini ve psikolojisini derinlemesine bilmelidir (Kanter, 2014, s. 256).

\section{1. Çocuk Edebiyatında Şiddet ve Olumsuzluklar}

"Çocuğa görelik" ilkesinden de anlaşılmaktadır ki, “çocuğa görelik” ilkesinin göz ardı edildiği çocuk edebiyatı eserleri, çocuğu duygusal ve düşünsel olarak beslemekten ziyade onu geriletebilir ve çocuğun dünyasında telafisi mümkün olmayan veya çok zor olan hasarlara yol açabilir. Yazarın okuruna sunduğu eser, çocukların temel ihtiyaçları olan sevgi, ilgi ve güven duygusunu hissettirecek, dostça duyguların yanı sıra çocukları tedirgin edebilecek, korkutacak veya onların kaygılanmalarına neden olacak olumsuzlukların üstesinden gelinebilir olduğunu hissettirecek özelliklere sahip olmalıdır (Tekin, 2005, s. 306). Bu olumsuzlukların tetikleyici unsurlarından biri, çocuk edebiyatına yansıtılan şiddettir. Son çeyrek yüzyılda ekonomi politikalarının sosyal politikaların önüne geçmiş olması nedeniyle toplumda şiddet artmış ve şiddet içerikli yayınlar kontrol edilemez hâle gelmiştir. Aile değerlerimizin erozyona uğraması ile birlikte aile içi şiddetin yanı sıra çocuk ve şiddet konusu da çocuk edebiyatının önemli bir konusu hâline gelmiştir (Turan, 2015, s. 203).

Son yıllarda çocuklara yönelik film, oyuncak ve kitaplarda şiddet içerikli unsurlar ön plana çıkarılmıştır. Çocuklar için hazırlanan çizgi filmler, oyunlar $v b$. görsellerin büyük bir çoğunluğunda olaylar kaynağını 
şiddetten almakta; şiddet sorun çözmenin yöntemlerinden biri şeklinde sunulmaktadır. Bu durumda çocukların kişilik özelliklerinin oluşumunda sorunlarla karşılaşlabileceği düşünülebilir (Sever, 2002, s. 32). Çocukların ilk karşlaş̧tıkları kitaplarda yürek söken avcılar, zehirleyen üvey anneler, yakılan cadılar olması çocukların bu tür duyguları küçük yaşlardan itibaren geliştirmelerine sebep olabilecektir (Sever, 2003, s. 16).

Çocuğun bulunduğu veya erişebildiği ortamlarda (medya, aile ortamı, arkadaş ortamı, eğitim kurumları vb.) şiddete yer verilmesi çocuğun dolaylı olarak şiddete maruz kalmasına ve bu şiddet faktöründen pasif olarak etkilenen konumda olmasına neden olabilmektedir. Ancak herkes tarafindan bilinmektedir ki şiddet yaşamın bir gerçeğidir. Çocuğa görelik ilkesine uygun olarak şiddetin ölçülü olarak sezdirilmesi çocuğun şiddetle baş etmesi konusunda çocuğa yardımcı olabilmektedir.

Kitaplarda, yaşamın bir gerçeği olan şiddet olgusuna yer verilebilir. Ancak, çocukların yaş ve gelişim özellikleri dikkate alınarak yer verilen şiddet unsurları, çocukları şiddete karşı neler yapılması gerektiği konusunda bilinçlendirmeli, onlarda şiddet ve kaba kuvvete karşı bir anlayış oluşturabilmelidir. Özellikle, çocuklara bireysel ve toplumsal ilişkilerde ortaya çıabilecek sorunların çözümünde en etkili yöntemin "iletişim" olduğu sezdirilmelidir (Sever, 2003).

Alan yazında çocuk edebiyatındaki şiddet ve olumsuzlukları konu edinen çalışmalardan bazılarına yönelik elde edilen sonuçlar Tablo 1'de yer almaktadır.

Tablo 1. Çocuk Edebiyatında Şiddeti ve Olumsuzlukları Ele Alan Çalışmalar

\begin{tabular}{|c|c|c|}
\hline Yazar/lar & Konu & Sonuç \\
\hline $\begin{array}{l}\text { Karagöz } \\
(2017)\end{array}$ & $\begin{array}{l}\text { Türkçe Öğretmeni } \\
\text { Adaylarının Çocuk ve } \\
\text { Gençlik Edebiyatı } \\
\text { Yapıtlarının Temel } \\
\text { Özelliklerini Bilme } \\
\text { Yeterlikleri }\end{array}$ & $\begin{array}{l}\text { Türkçe öğretmeni adaylarının çocuk ve gençlik edebiyatının } \\
\text { biçimsel özelliklerine ilişkin yeterlik düzeylerinin güçlü olduğu, } \\
\text { ancak içerik açısından güçlü bir yeterliğe sahip olmadıkları tespit } \\
\text { edilmiştir. Öğretmen adayları çocuk ve gençlik yayınlarının içerik } \\
\text { kısmıyla ilgili olarak çoğunlukla kitapların ögüt taşıması gerektiği, } \\
\text { çocuğu ve genci eğitme olanağı yaratması gerektiği şeklinde görüs } \\
\text { bildirmişlerdir. Bu, öğretmen adaylarının çocuk ve gençlik } \\
\text { edebiyatı yapıtlarına karşı yararcı bir bakış geliştirdiklerini } \\
\text { gösterir. Bu durumun öğretmen adaylarını günümüzün çocuk ve } \\
\text { gençlerine hitap etmekte, çocuk ve genç okuru kitaba ve okuma } \\
\text { alışkanlığına teşvik etmekte etkisiz kılacağı açıtır. Araştırmanın } \\
\text { sonucunda öğretmen adaylarının çocuk ve gençlik edebiyatı } \\
\text { konusunda gelişimine katkı sağlayacak birtakım önerilerde } \\
\text { bulunulmuştur. }\end{array}$ \\
\hline
\end{tabular}

Aktaş \& $\quad$ Çocuk Edebiyatı Açısından Uzuner Yurt Ỏmer Seyfettin'in (2016) Hikâyelerinde 'Çocuğa Göre’ Olmayan Unsurlar

Çocuk Edebiyatı Elleştirisinin Türkçe Lüle Mert Öğgretmen Adaylarının (2016) Çocuk Kitaplarını Gelişim Düzeylerine Göre Ayrıştırma Becerisine Etkisi

Sen (2016) Çocuk Edebiyatında Bir Yaşam Gerçekliği Olarak Ölüm Olgusu Üzerine Bir
Araştırma sonucunda yazarın hikâyelerinde; savaş, ölüm, şiddet, karamsarlık, pişmanlık, cinsellik, ötekileştirme, rrk ve cinsiyet ayrımcılığı gibi olumsuz unsurlara rastlandığı tespit edilmiştir.

Çocuk edebiyatı eleştirisi Türkçe öğretmeni adaylarının, çocuk kitaplarını gelişim düzeylerine göre ayırt etmelerini olumlu yönde etkilemektedir. Çocukların okuma kültürünü kazanmalarının en önemli aşaması, ailelerin ve öğretmenlerin çocukları edebî niteliğe sahip çocuk kitaplarıyla buluşturması ve kitapların yazarlar tarafindan sanatsal bir duyarlılıkla oluşturulmalarıdır.

Ölüm, karamsar bir olgu olarak ele alınmamıs ve bir yaşam gerçeği olarak yansitılmıştır. Yazar karakterlerin ölümünü, biyolojik bir tükenme ve yaşamın bir parçası olarak ele almaktadır. Karakterlerin, ölüm olgusunu yaşamın bir parçası 


\begin{tabular}{|c|c|}
\hline & $\begin{array}{l}\text { İnceleme (Sevim AK } \\
\text { Örneği) }\end{array}$ \\
\hline $\begin{array}{l}\text { Karataş } \\
(2014)\end{array}$ & $\begin{array}{l}\text { Çocuk Edebiyatında } \\
\text { "Karakter" Kavramı }\end{array}$ \\
\hline Uluğ \& & Determination of the \\
\hline $\begin{array}{l}\text { Bayraktar } \\
(2014)\end{array}$ & $\begin{array}{l}\text { Required Features of } \\
\text { Children's Picture Books }\end{array}$ \\
\hline
\end{tabular}

Çakır (2013) $\quad$ Ö̈rkçülerin Cocuğa Görelik

Açısından İncelenmesi

Gönen,

Ertürk \&

Özen

Altınkaynak Approaches In Children's

(2011)

Temizkan

(2011)

Lelli (2010)

Dağlığlu \&

Çamlıbel

Çakmak

(2009)

Aytekin

(2008)

\begin{abstract}
olarak kabullenmeleri çocuk okur açısından da önemlidir. Böylece çocuk okur da özdeşim kurduğu karakterler aracılığıyla ölümü, yaşamın bir gerçeği olarak kabul edebilir.
\end{abstract}

Çocuklar 3-6 yaş arasında çevrelerindeki kişileri veya film, animasyon, kitap gibi ürünlerdeki kahramanları örnek almaktadırlar. Bu durum ilerleyen yaşlarda azalmakta, ergenlik döneminde önemli bir sürece girmektedir. Kurgusal ürünlerdeki karakterlerden bazıları sıra dışı güçler ve fiziksel özellikleriyle çocukların gözünde ideal rol model olabilmektedir. Bu "her şeye sahip olan ve her şeyi yapabilen" karakterler çocuğun gerçeklik algısında bozulmalara neden olmaktadır.

Çocuk resimli kitapları çocuğun bilişsel, dil ve kişilik gelişiminde önemli bir rol oynamaktadır. Ayrıca hayal gücü, kelime ve dil gelişiminin yanı sıra, çocuklar için dramatik bir deneyim sağlar. Bu nedenle belirlenen kriterler doğrultusunda çocuk edebiyatının muhatabı olan kitleye (okuyucu, yayıncı, illüstratör, veli ve öğretmenlere) birtakım öneriler sunulmuştur.

Tasarım özellikleri açısından öykülerde kullanılan resimler metinlerle ilişkilidir. Ancak aynı resimlerdeki nesneler ve tiplemelerin çocuğa göre olmadı̆̆ı, gereksiz resimlerin çokça kullanıldığı ve metnin önüne geçtiği görülmüştür. İçerik özeliklerinden elde edilen sonuçlarda ise metinlerde çocuğun dikkatini çeken ve ilgi alanına giren konular işlenmemiş, otoriter yaklaşım kullanılmıştır. Dil ve anlatım yanlışlıkları ise metin seçiminde seviyenin göz önünde bulundurulmadığını ortaya koymaktadir.

Okul öncesi öğretmenlerinin çocukların okuma amaçlarını belirlerken, okuma alışkanlığı kazandırdıkları, okuma köşeleri oluşturdukları, farklı hikâye anlatma teknikleri uyguladıkları, çocuk kitapları için tema seçtikleri, okumadan önce, okuma sırasında ve sonrasında farklı teknikler kullandıkları ancak yenilikçi ve yaratıcı uygulamalar kullanmadıkları tespit edilmiştir.

Türkçe öğretmeni adayları çocuk kitaplarının dış özellikleri konusunda ortalamanın üzerinde bilgi düzeyine sahiptir. Öğretmen adaylarının içerik özellikleri konusunda ise yeterli bilgi düzeyine sahip olmadıkları tespit edilmiştir.

Çocuk edebiyatı dersi, öğretmen adaylarının, öğretmenlik yaptıkları öğrencilerin davranışlarındaki aile içi şiddet belirtilerini tanımak konusundaki bilgi ve becerilerini arttırmıştır.

Genel olarak hikâye kitaplarının içerik ve görsellerinde ortalama \% 8 şiddet, \% 11 korku ögesi bulunmuştur. Bu ögeler daha çok çeviri ve dünya klasikleri kitaplarında tespit edilmiştir.

Ölüm bir yaşam gerçeğidir ve çocukların bu olayı anlamasına çocuk edebiyatı ile yardımcı olunmaya çalışılabilir. Okuduğu hikâyelerde ölüm içeren olaylarda çocuk bu olayı anlamakta çok zorlansa da zamanla anlamaya başlar ve eskisi gibi korku duygusuna kapılmaz. Ancak tamamen şiddet içeren ve ölümü "öldürme" yoluyla ortaya koyan eserler çocuklar için oldukça tehlikelidir. 


$\begin{array}{ll}\text { Hökelekli } & \text { Çocuk ve Gençlerde Şiddet } \\ \text { (2007) } & \text { Olgusu ve Önlenmesine } \\ & \text { Yönelik Öneriler }\end{array}$

Fantastik Çocuk

Kara (2007) Kitaplarında Uzamın

İmgesel İşlevi ve Şiddet $\begin{array}{ll}\text { Sever (2007) } & \text { Çocuk Edebiyatı Öğretimi } \\ \text { Nasıl Olmalıdır? }\end{array}$

$\begin{array}{ll}\text { Turan } & \text { Violence and Death in } \\ \text { (2006) } & \text { Stories of War Period } \\ & \text { Writer Omer Seyfettin }\end{array}$

Okuma Hedefleri

Dilidüzgün Bağlamında Türkçe Ders

(2004) Kitaplarındaki Çocuk

Edebiyatı Ürünleri

Sever (2002) Çocuk Kitaplarına

Yansıtılan Şiddet

$\begin{array}{ll}\text { Nimon } & \text { Violence in Children's } \\ \text { (1993) } & \text { Literature Today. }\end{array}$

Nimon

Literature Today.

Violence in Children's

Literature: A Content

Analysis of a Select

Blatt (1972) Sampling of Children's

Literature and a Study of

Children's Responses to

Literary Episodes

Depicting Violence
Şiddet, çocukluk döneminde ortaya çıkan ve sonraki dönemlerde kronikleşme eğilimi gösteren bir olgu olduğundan şiddet davranışını önlemeye yönelik çabaların çocukluk döneminde yoğunlaştırılması gerekir.

Fantastik çocuk kitapları şiddeti, gerçekliğe gönderme yapmayan bir imge gibi gösterir ve gizler. Bilinçli olarak tercih edilen bu imgeler şiddetin dayattı̆̆ bir duruma gönderme yapar. Şiddet, içerik ve görseller ile ortaya konulurken okur ve izleyici şiddet ile imgeyi birbirine karıştırır; imge şiddete, şiddet imgeye dönüşür.

Öğretmen adaylarına çocuk edebiyatının temel niteliklerini ve çocuğun yaşamındaki yerini kavratmak, çocuk edebiyatı öğretiminin temel amacı olmalıdır. Çocuk edebiyatında yer alan kuramsal temeller, uygulamalarla örneklendirilmelidir.

Veriler, bu hikâyelerde ölüm ve şiddete hangi düzeyde ortaya konulduğunu belirlemek için bilgisayar destekli kantitatif analize tabi tutulmuş, Ayrıca, öyküdeki ölüm ve şiddet konusu, çeşitli kategorilere ayrılarak incelenmiştir. Öykülerde işlenen ve bireysel ölümlerin nedeni olabilen intihar, şiddet, infaz ve yaralanma konuları ele alınmıştır. Bu hikâyelerin şiddet dolu içeriklerinin çocuklar açısından anlamı ise "çocuğa görelik" ilkesi açısından uygun değildir ve endişe uyandırmaktadır.

Türkçe ders kitaplarında bulunan metinler, öğrencilerin yaş ve gelişim özelliklerine uygun olmalıdır, Çocuklar ve gençler için üretilen edebî nitelik taşıyan metinler Türkçe ders kitaplarında yer almalıdır. Ancak; Türkçe ders kitaplarının biçimsel olarak çocuğa göre olsa da nitelik olarak uygun olduğu söylenemez. Metinler üzerine yapılan çalışmalar metin çözümleme, pekiştirme ve sınama özelliklerini barındırmamaktadır. Okuma becerisinin gelişebilmesi, Türkçe ders kitaplarında bulunan metinlerin seçiminde nitelikli çocuk edebiyatı ürünlerinin yer almasına bağlıdır. Metinler üzerine yapılan çalışmaların yaratıcı etkinlik ve çalışmalarla desteklenmesi gerekir.

Çocuk kitabı yazarlarının çocuk kitaplarında niteliği belirleyen ilkeleri uygulayabilmeleri ile kitapları işlevlerini gerçekleştirmeleri arasında anlamlı bir ilişki vardır. Bu ilişki, kitapları hem çocukların ruhsal dünyasını etkileyen olumsuz bir unsur olmaktan çıkaracak hem de "Millî Eğitim Temel Yasası" ile "Çocuk Haklarına Dair Sözleşme” hükümlerinin uygulanmasına katkı sağlayacaktır.

Son yıllarda çocuk kitaplarında şiddetin yeri sorgulanmaktadır. Mevcut bazı bakış açıları, çocuk kitaplarının şiddet ve çatışmayı kapsayabileceğine işaret etmektedir, ancak bu durum, sunulan şiddetin ne şekilde ortaya konulduğu gerçeğini sorgulatmaktadır. Çocuk edebiyatında şiddete yer verilmesi gerektiği kabul edildiğinde, hangi kitapların kabul edilebilir düzeyde olduğuna karar vermek zordur. Çocuklara, kendi sorunlarına ve ilgi alanlarına uygun olan ve bu neticede anlamlı olan konuları ortaya koyan kitapların okutulması önemlidir.

İçerik analizinden elde edilen sonuçlar, çocuk kitaplarının şiddet içeriklerinde önemli bir artış olmadığını ortaya koymuştur. Şiddet içeren eylemlerin çoğunluğu duyusal bir şekilde tanımlanmış ve çocukların saldırganlık hakkındaki değer yarglları bu tür eylemlere karşı olduklarını göstermektedir. Çocukların verdikleri yanıtlara bakıldığında, şehir merkezinde ve kırsal kesimde yaşayan çocukların, şiddet içeren bölümleri sevmedikleri saptanmıştır. Kullanılan ankete verilen bireysel cevaplar ile kişilik özelliklerinin ölçülmesi arasında bir ilişki olmadığı görülmüştür. 
Tablo 1 incelendiğinde alan yazın derlemesi sonucunda çocuk edebiyatında şiddeti, olumsuzlukları ve çocuğa göre olmayan unsurları ele alan pek çok çalışmaya rastlanmıştır. Ayrıca çocuk edebiyatına yönelik olarak hem çocuk edebiyatı eserlerinin nitelikleri açısından hem de içerik özelliklerinin değişkenleri açısından, öğretmen adaylarının ve çocukluk çağında olan öğrencilerin görüşlerinin incelendiği çalışmaların da yer aldığı görülmektedir. Çocuk edebiyatında şiddeti ortaya koyan çalışmaların geneline bakıldığında, çoğunluğun eser inceleme ve incelenen eserlerin çocuk edebiyatının temel nitelikleri bağlamında analiz edildiği görülmektedir. Eser inceleme yoluyla ortaya konan bulgular, çocuk edebiyatı adı altında okutulan pek çok eserin, çocukların bulunduğu yaş grubuna hitap etmediğini ve çocuğa göre olmayan unsurları bünyesinde barındırdığını göstermektedir.

Tablo 1'e göre incelenen bir başka boyut ise öğretmen adaylarının çocuk edebiyatının temel niteliklerini bilme yeterlikleri üzerine yapılandırılmıştır. Yapılan çalışmalar neticesinde öğretmen adaylarının içerik açısından yeterlik konusunda eksik kaldığı saptanmıştır. Öğretmen adaylarının çocuk edebiyatının içeriği konusunda eksik kalmaları, çocuk edebiyatı eserlerine eleştirel yaklaşım sergilemelerini engelleyecek ve çocuğa göre olmayan unsurları bünyesinde barındıran eserleri, olduğu gibi çocuklara önerecek, bu durum da çocuğun hem bilgi düzeyinde hem de duygu dünyasında telafisi mümkün olmayan ya da çok zor olan sonuçları beraberinde getirebilecektir. Öğretmen adayı, hitap edeceği yaş grubunun psikososyal gelişim özelliklerini iyi bilmeli ve çocukların ilgi alanlarına uygun olan ve edebî nitelik taşıyan eserlere öncelik vermelidir.

Alan yazın incelendiğinde şiddet olgusuna yer verilmesi gerektiğini savunan çalışmaların sayıca fazla olduğu görülmektedir. Bu çalışmalar göstermektedir ki şiddet, çocuk edebiyatı eserlerinde çocuğa göre yansıtılmalı ve çocuksu duyarlılıkla çocuğa sunulmalı, çocuğa eleştirel düşünme becerisi kazandırmak amacıyla şiddetin olumsuz sonuçlarının etkileri çocuğun çıkarımda bulunmasına olanak verecek şekilde, özenti oluşturmadan ele alınmalıdır. Yapılan çalışmaların sonucuna bakıldığında şiddete yer vermeyerek yaşamdan kopukluk yaratmanın, çocuğun gerçek dünya ile ilgili algılarında bozulmalara neden olabileceği sonucuna varılabilir. Bu bozulmaların önüne geçebilmek de duyarlı öğretmenlerin ve ailelerin çocuk edebiyatına uygun, nitelikli edebî eser seçimiyle mümkün olabilecektir.

Bu çalışma, öğretmen adaylarının çocuk edebiyatında yer alan şiddet unsurlarının ne derece farkında olduklarını ortaya koymak açısından önem arz etmekte ve bu çalışmanın, geleceğin öğretmenlerinin çocuk edebiyatı eserlerini çocuklara önerirken "şiddet" gerçeğinin sunulma biçimi ve sonuçlarından haberdar olmasına olanak sağlayabileceği düşünüldüğünden, alan yazın açısından önemli olduğu değerlendirilmektedir. Bu duyarlılıkla çocuk edebiyatı dersini almış olan öğretmen adaylarının ön bilgilerinden hareketle, şiddet dilinden haberdar olmalarını ve şiddetin yansıtılma biçiminin farkında olmalarını sağlaması açısından yapılan çalışmanın önemli olduğu düşünülmüş ve alan yazında şiddet dilini ölçen bir çalışmanın gerekliliği saptandı̆̆ından, böyle bir çalışma yapılmıştır.

\section{Yöntem}

Bu araştırma öğretmen adaylarının çocuk edebiyatında şiddet dili farkındalıklarını belirleyecek bir ölçek geliştirmek amacıyla yapılmıştır. Bu kapsamda çocuk edebiyatında şiddet dili farkındalık ölçeği geliştirilmiştir.

\section{1. Çalıșma Grubu}


Araştırmanın çalışma grubunu, Erzurum Atatürk Üniversitesi’nde Türkçe eğitimi, sınıf eğitimi ve okul öncesi eğitimi alanlarında öğrenim görmekte olan öğretmen adayları oluşturmaktadır. Çalışma grubu, ölçüt örnekleme yöntemine göre belirlenmiştir. Öğretmen adaylarının lisans düzeyinde çocuk edebiyatı dersini almış olmaları ölçüt olarak değerlendirilmiş ve çalışma grubunu, çocuk edebiyatı dersini almış olan öğretmen adayları oluşturmuştur. Ölçek geliştirme çalışması sürecinde 3 farklı çalışma grubu üzerinde çalışılmıştır. Birinci çalışma grubu 30 kişilik çocuk edebiyatı dersini almış Türkçe öğretmeni adayından oluşmaktadır. Bu çalışma grubuna formun anlaşılırlığını kontrol etmek için araştırmacı tarafından sesli bir şekilde maddeler okunmuş ve anlaşılması güç olan maddeler üzerinde tekrar çalışılmıştır. İkinci çalışma grubunu 232 öğretmen adayı oluşturmaktadır. Bu gruptan elde edilen verilere de açımlayıcı faktör analizi yapılmıştır. 232 kişilik ikinci çalışma grubunda yer alan öğretmen adaylarının cinsiyet değişkenine göre 170’inin kız (\%73,3), 62'sinin erkek (\%26,7) olduğu; sinıf değişkenine göre 148'inin 3. sınıf (\%63,8), 84'ünün 4. sınıf $(\% 36,2)$ olduğu; bölüm değişkenine göre 81'inin okul öncesi (\%34,9), 45’inin sınıf eğitimi (\%19,4) ve 106'sının Türkçe eğitimi (\%45,7) ana bilim dalında öğrenim görmekte olduğu belirlenmiştir. Araştırmanın üçüncü çalışma grubunu ise 181 öğretmen adayı oluşturmaktadır. 181 kişilik üçüncü çalışma grubunda yer alan öğretmen adaylarının cinsiyet değişkenine göre 132'sinin kız $(\% 72,9)$, 49'unun erkek $(\% 27,1)$ olduğu; sinıf değişkenine göre 126’sının 3. sinıf (\%69,6), 55’inin 4. sınıf $(\% 30,4)$ olduğu; bölüm değişkenine göre 70’inin okul öncesi $(\% 38,7)$, 42'sinin sınıf eğitimi (\%23,2) ve 69'unun Türkçe eğitimi $(\% 38,1)$ ana bilim dalında öğrenim görmekte olduğu belirlenmiştir. Bu gruptan elde edilen verilere de doğrulayıcı faktör analizi yapılmıştır. $\mathrm{Bu}$ üç çalışma grubu da birbirinden bağımsızdır. Son olarak elde edilen verilere ilişkin güvenirlik analizleri yapılmıştır.

Açımlayıcı Faktör Analizi ve Doğrulayıcı Faktör Analizi için belirlenen çalışma gruplarında madde sayısının 5 ve 10 katı olmasına dikkat edilmiştir. Kline (1994) faktör analizi için 200 kişinin yeterli olabileceğini belirtmektedir. Ayrıca madde sayısının 10 katı örneklem büyüklüğüne ulaşılmasının iyi olacağını belirtmesine rağmen en az 2 katı olabileceğinden de söz etmektedir. Tabachnich ve Fidell (2015) faktör analizi için 300 katılımcının olmasının rahatlatıcı olacağını belirtmektedirler. Ancak veri setinde yüksek yüke sahip birkaç değişkenin olması durumunda 150 katılımcının da yeterli olacağını belirtmektedir. Ayrıca Tabachnich ve Fidell (2015) ve Tavşancıl (2014) her bir madde için beş katılımcının da yeterli olacağını belirtmektedirler. Bu bağlamda bu araştırmada açımlayıcı faktör analizi için madde sayısının 5 katı, doğrulayıı faktör analizi içinde madde sayısının 10 katı katılımcı üzerinde çalışılmıştır.

\subsection{Veri Toplama Aracı}

Alan yazın incelendiğinde hem yurt içinde hem de yurt dışında çocuk edebiyatında şiddeti ele alan pek çok çalışmaya rastlanmıştır. Ancak ölçek formatında çocuk edebiyatında şiddeti ele alan bir çalışmanın yer almadığı görülmektedir. Öğretmen adaylarının çocuk edebiyatında şiddet diline yönelik farkındalıklarını belirlemek için kullanılan ölçek, araştırmacılar tarafından aşağıda belirtilen aşamalardan geçerek geliştirilmiştir.

"Çocuk Edebiyatında Şiddet Dili Farkındalık Ölçeği” için öncelikli olarak alan yazın taraması yapılmış ve ölçek maddeleri için beş farklı tema oluşturularak (çocuk edebiyatı metni nitelikleri, okur evrenine göre şiddetin yansıtılma durumu, içerik, yansıtılan şiddetin türleri ve olası etkileri, yazarın yönlendirme tercihi) bu temalar doğrultusunda çocuk edebiyatında şiddet dili farkındalığını ortaya koymak üzere 50 maddeden oluşan bir madde havuzu oluşturulmuştur. Bu madde havuzu oluşturulurken şiddet ile ilgili olarak psikoloji ile psikolojik danışma ve rehberlik alanlarında çalışmakta olan uzmanların, çocuk 
edebiyatı alanlarında ise Türkçe Eğitimi ve Türk Dili ve Edebiyatı alanlarında çalışmakta olan uzmanların görüşleri dikkate alınmıştır. Oluşturulan temalar aynı uzmanlar tarafından incelenmiştir. Gruplandırılan temalar çocuk edebiyatında şiddet dilini ne derece ölçebileceği dikkate alınarak uzmanlar tarafından tekrar gözden geçirilmiştir. Oluşturulan maddelerden bazılarının alan konusunda üst düzey beceri gerektirmesi, bazılarının birden fazla alanla ilgili olması, bazı madde köklerinin ise farkındalık ölçeğine uygun olmaması nedeniyle ilgili maddeler madde havuzundan çıkarılmıştır. Yapılan çalışmalar doğrultusunda madde sayısı 39'a indirilmiştir. Ölçeğin değerlendirilmesinde uzmanların görüşleri dikkate alınarak likert tipi puanlamanın yapılmasına karar verilmiştir.

\subsection{Verilerin Analizi ve İşlem}

Araştırmada geçerlik çalışmaları doğrultusunda kapsam ve yapı geçerliği incelemesi yapılmıştır. Kapsam geçerliğini sağlamak amacıyla yukarıda belirtildiği üzere alan yazın incelemesi yapılmış, ölçme aracında yer alan sorular uzmanlar eşliğinde oluşturularak görüş alınması için 3 rehberlik ve psikolojik danışmanlık, 1 eğitim programları ve öğretim, 3 Türk dili ve edebiyatı eğitimi, 2 Türkçe eğitimi, 1 psikoloji alanında olmak üzere toplamda 10 uzmana gönderilmiştir. Uzmanlar tarafından verilen dönütler neticesinde ölçeğe son hâlinin verilmesi için alan uzmanları ile birlikte toplantı düzenlenerek maddeler tartışılmış ve ölçek maddelerine son hâli verilmiştir. Maddelerin açık ve anlaşılır olduğundan emin olmak için 30 Türkçe öğretmeni adayına ölçek maddeleri okunmuş ve onların görüşleri alınarak maddelere gerekli düzeltmeler yapılmıştır. Ölçeğin amacını ortaya koymak ve işaretleme aşamalarını belirtmek üzere bir yönerge hazırlanmış ve ölçek maddelerinden önce olgusal form hazırlanmıştır. Hazırlanan olgusal formda öğretmen adaylarının işaretleme yapmaları için sınıf, bölüm ve cinsiyet değişkenlerine yer verilmiştir. Olgusal formdan sonra öğretmen adaylarının işaretleme yapmaları için 39 maddeden oluşan ölçek formu hazırlanmış ve maddelerin ortasına (18.madde) "bu maddeyi boş bırakınız." maddesi eklenmiş ve öğretmen adaylarının ölçek maddelerini doğru bir şekilde okuyarak işaretlediğinden emin olunmaya çalışılmış, bu madde üzerinde işaretleme yapan 18 öğretmen adayının formları ölçeğin güvenirliği açısından analiz dışında tutulmuştur. 232 öğretmen adayından elde edilen verilerin faktör analizine uygunluğu Kaiser-Meyer-Olkin (KMO) katsayısı ve Bartlett küresellik testi ile incelenmiştir. Bu aşamadan sonra geçerlik çalışmaları kapsamında açımlayıcı faktör analizi (AFA) ve doğrulayıcı faktör analizi (DFA) yapılmıştır.

AFA ölçülmek istenen faktörler ile ilgili araştırmacıya bilgi verebilmektedir (Tavşancıl, 2014). Diğer bir ifadeyle AFA bir ölçme aracındaki değişkenlerin kaç alt faktör altında toplandığını ve aralarındaki ilişkiyi belirlemek için kullanılır (Seçer, 2015, s.78). AFA'da yapılan değerlendirmelerde faktör yükleri en az 0,30 olan maddeler kabul edilir (Büyüköztürk, 2008; Cathell ve Baggaley, 1960; Neale ve Liebert, 1980). Bu sebeple faktör yükü o,3o'un altında olan maddeler ölçekten çıkartılmıştır. AFA'da öz değerleri 1'den büyük olan faktörler üzerinde gerekli uygulamalar yapılmalıdır (Tabachnick ve Fidell, 2015). Bundan dolayı öz değerleri 1'den küçük olan faktörler dikkate alınmamıştır. Daha sonra faktör analizi sonucunda ortaya çıkan faktörler paralellik testi ile kontrol edilmiştir. Paralellik Testi verilerin öz değerleri ile aynı şekilde ancak rastlantısal bir şekilde elde edilen diğer öz değerlerin kıyaslanması esasına dayanır (Pallant, 2017, s. 202). Bu sebeple AFA sonuçları Monte Carlo Paralellik Testi (Watkins, 2000)'yle de karşılaştırılmıştır. Ölçeğin son uygulaması sonucunda elde edilen verilerin doğrulanması için Doğrulayıcı Faktör Analizi (DFA) yapılmıştır. DFA yapılırken ön uygulama ile aynı özellikleri taşıyan ancak farklı bireylerden oluşan katılımcılara ulaşılmıştır. AFA ile elde edilen verilerin DFA ile doğrulanabilmesi için birtakım temel değerlerin (normallik, çoklu bağlantıllk, örneklem büyüklüğü) hesaplanması gereklidir (Kline, 2005; Tavşancıl, 2014, s.51). Bu sebeple öncelikle normallik, çoklu bağlantılık, örneklem büyüklüğü analizleri yapılmıştır. Ulaşılan değerler RMSEA, SRMR, GFI, AGFI, 
NFI, $\chi 2$ /sd, TLI ve CFI uyum ölçütleri ile test edilmiştir. Ölçeğin güvenirliğini belirlemek için ise Cronbach Alpha iç tutarlılık katsayısı ve iki yarı güvenirlik testi katsayıları hesaplanmıştır.

\section{Bulgular}

\section{1. Ön Analizler}

Açımlayıcı faktör analizine geçmeden önce verilerin analizlere uygunluğu kontrol edilmiştir. Öncelikler eksik veriler, uç değerler, ters maddeler, normallik, örneklem sayısı ve örneklem uygunluğu kontrol edilmiştir. Eksik verilerin tamamlanmasında ilgili maddeye ilişkin aritmetik ortalamalar dikkate alınarak düzeltmeler yapılmıştır. Uç değerler grafiklerle kontrol edilmiştir. Ters madde olan 21., 22. ve 39. maddeler ters çevrilmiştir. Veri setinin normalliğine Kolmogorov-Smirnov testi ( $p>.05$ ), Q-Q plot ve box plot grafikleri, mod, medyan ve aritmetik ortalama değerleri ile skewness ve kurtosis değerleri incelenmiş ve veri setinin normal dağılıma uygun olduğu sonucuna ulaşılmıştır.

Ayrıca açımlayıcı faktör analizine geçmeden önce Cronbach Alpha iç güvenirlik katsayısı hesaplanmış ve doğrulanmış madde toplam korelasyon katsayısı çok düşük olan ve güvenirliği de düşüren maddeler incelenmiş ve özellikle eksi (-) değerler olan maddeler ölçekten çıkarılmıştır. Bu kapsamda güvenirliği ciddi anlamda düşüren 13., 16., 21., 23., 30. ve 38. Maddeler ölçekten çıkarılmıştır. Ölçekten madde çıkarmadan önce hesaplanan Cronbach Alpha iç güvenirlik katsayısı .849 iken, güvenirliği düşüren maddeler çıkarıldıktan sonra hesaplanan Cronbach Alpha iç güvenirlik katsayısı .889'dur.

\subsection{Açımlayıcı Faktör Analizi}

232 kişilik öğretmen adayından toplanan verilerin açımlayıcı faktör analizine uygun olup olmadığını belirlemek için sırasıyla örneklem sayısı için Kaiser-Mayer-Olkin (KMO) değeri ve örneklem uygunluğu için Barlett Küresellik Testi yapılmıştır. Güvenirlik analizi öncesi hesaplanan KMO değeri .836 iken, güvenirliği düşüren 6 madde ölçekten atıldıktan sonra hesaplanan KMO değeri .868'dir. Tabachnich ve Fidell (2015) KMO değerinin alt sınırını .6 olarak belirtmiştir. Bu sonuç örneklem sayısının kabul edilebilir olduğunu göstermektedir. Barlett Küresellik testi sonuçları incelendiğinde (Ki Kare= 2260,138; $\mathrm{df}=528 ; \mathrm{p}<.05$ ) ise verilerin faktör analizine uygun olduğunu göstermektedir (Field, 2009).

Faktör sayısını belirlemek için özdeğerin 1'den büyük olması, açıklanan toplam varyansın oranı ve yamaç-birikinti grafiğidir (Field, 2009). İlk çözüm ölçeğin 8 faktör yapısı toplam varyansın \%55.2'sini açıkladığını göstermektedir. Ancak faktörlere dağılan maddelerin faktör yükleri incelendiğinde 16 maddenin iki farklı faktör altında yüksek faktör yüklerine sahip olduğu ve binişik maddeler olduğu belirlenmiş ve ölçekten çıkarılmasına karar verilmiştir. Tekrar yapılan işlemler sonucunda 3 faktör yapısının toplam varyansın \%48.294'ünü açıkladığı sonucuna ulaşılmıştır. Temel bileşenler analizi ile kritik değerlerin öz değerlerle karşılaştırılmasına ilişkin yapılan paralel analiz sonucu Tablo 2'de yer almaktadır.

Tablo 2. Temel Bileşenler ile Kritik Değerlerin Öz değerlerle Karşılaştırılması

\begin{tabular}{cccc}
\hline Bileşen No & Temel Bileşenler Analizi & Paralel Analiz Kriter Değer & Karar \\
\hline 1 & 6,251 & 1,5292 & Kabul \\
\hline
\end{tabular}


“Violence Language” Awareness Scale in Children's Literature: Validity and Reliability Study / L. Turan, F. Gerez Taşgın (p. 232248)

\begin{tabular}{|c|c|c|c|}
\hline 2 & 1,423 & 1,4158 & Kabul \\
\hline 3 & 1,104 & 1,3392 & Red \\
\hline
\end{tabular}

Yapılan Monte Carlo paralellik testi ile ölçek faktörleri arasında farklılık olduğu görülmektedir. Monte Carlo paralellik test değerlerine göre ölçeğin iki faktörlü yapıda olmasının daha uygun olacağı sonucuna ulaşılmıştır. Son uygulama için ölçekte bulunan madde sayısı 17 olarak belirlenmiştir. Ölçeğin ön uygulamaya ait faktör analizi sonuçları Tablo 3’te gösterilmektedir.

Tablo 3. Çocuk Edebiyatında Şiddet Dili Farkındalık Ölçeği Açımlayıcı Faktör Analizi - Faktör Yükleri

\section{No Ifadeler}

Dinî unsurların baskıcı bir tutumla verilmesi (dinin gereklerini yerine

19 getirmeyenler kötüdür $v b$.), çocuğun din ile ilgili algılarında bozulmalara neden olmaktadır.

Din ile ilgili kavramların korku yoluyla kazandırılmaya çalışılması (Allah yakar, cehennemde yanarsın $v b$.) çocuğun din ile ilgili algılarında bozulmalara neden olmaktadır.

Aile içi ilişkilerin olumsuz yansıtılması (babanın anneye bağırması vb.) çocuğun aile kavramına karşı olumsuz tutum geliştirmesine neden olmaktadır.

Bedensel engellerin alaycı tavırla ele alınması çocukların engelli bireylere karşı olumsuz tutum geliştirmelerine neden olur.

Acıma duygusunu ortaya çıkarmaya yönelik içerikler(falakaya yatırma, hayvan öldürme $v b$.)çocukları duygusal olarak olumsuz etkilemektedir. içermektedir.

Çeşitli varlıklara (insan, hayvan, nesne) karşı kaba kuvvet kullanılması çocukları fiziksel şiddete özendirir.

Simgesel olarak tehlike arz eden unsurların (bıçak, balta $v b$.) amacı dışında kullanılması (insana doğrultulması) çocukların şiddet ile ilgili algılarında olumsuzluklara neden olur.

Olumsuz çağrışım yapan yüz ifadelerinin (aşırı alaycı, kızgın ) sıkça yer alması, çocuğu duygusal olarak olumsuz etkilemektedir.

Küçümseyici (sert, kaba ve alaycı) konuşmalar çocukları sözel şiddete özendirir.

Şiddetin yetişkinlere göre verilmesi çocuğun duygusal gelişimini olumsuz etkilemektedir.

Belli bir duygu durumunun abartılarak verilmesi çocukları duygusal olarak olumsuz etkilemektedir.

Yazarların otoriter bir tutum sergilemesi (verdiği her iletinin doğru olduğunu düşünmesi) çocukları bu yönde şiddete teşvik eder.

Belli tiplerin aynı şekilde çocuğa sunulması (üvey annelerin her zaman kötülük yapması $v b$.) çocukta olumsuz kalıp yargılar oluşturur.
Görseller (kavga, cinsellik, korku vb.) çocuklar için psikolojik şiddet
Faktör Yükü

1. Faktör 2. Faktör 


\begin{tabular}{llc}
\hline $\mathbf{1 1}$ & $\begin{array}{l}\text { Çocukların maruz kaldığı şiddet içerikli unsurlar çocukların şiddete yatkın } \\
\text { bir birey olarak yetişmelerine neden olmaktadır. }\end{array}$ &, 676 \\
$\mathbf{8}$ & $\begin{array}{l}\text { Toplumsal cinsiyet rollerinin vurgulanması çocukların kişilik gelişiminde } \\
\text { bozulmalara neden olur. }\end{array}$ &, 671 \\
$\mathbf{1 0}$ & $\begin{array}{l}\text { Çocuğun psikososyal gelişimine uygun olmayan cinsel içerikler çocuğun } \\
\text { cinsel gelişimini olumsuz etkiler. }\end{array}$ &, 648 \\
\hline Açılanan Toplam Varyans (Toplam = \%44.223) & $\% 36.557$ & $\% 7.666$ \\
\hline Cronbach Alpha $=.887$ & $\alpha=.876$ & $\alpha=.67$ \\
\hline
\end{tabular}

Madde faktör yük değerleri Tablo 3 ’te incelendiğinde 1. faktör için madde faktör yüklerinin .739 ile .521 arasında değiştiği; 2. faktör için madde faktör yüklerinin ise .678 ile .648 arasında değişmekte olduğu görülmektedir. Ölçek geliştirmede faktör yük değerleri .45 ve üzerinde olması tercih edilebildiği (Büyüköztürk, 2008) gibi .40 ve üzerinde faktör yük değerlerinin de "çok iyi” olarak değerlendirildiği (Tabachnick \& Fidell, 2015) bilinmektedir. Bu bağlamda ölçeğe ilişkin en düşük madde faktör yük değerinin .521 olduğu dikkate alındığında maddelerin kabul edilebilir faktör yük değerlerine sahip oldukları söylenebilir. 13 maddeden oluşan 1. faktöre ilişkin maddeler incelendiğinde, bu maddeler "içerik" boyutu olarak 4 maddeden oluşan 2. faktöre ilişkin maddeler incelendiğinde de "etki" boyutu olarak adlandırılmıştır. 1. faktör toplam varyansın \%36.557'sini, 2. faktör ise toplam varyansın \%7.666'sını açıklamaktadır. İki faktörün açıkladığı toplam varyans \%44.223’tür. \%40 ve 60 arasındaki toplam varyans değerinin sosyal bilimlerde yeterli olduğu iddia edilmektedir ve bir faktörün anlamlı olması için açıklanan toplam varyansın en az \%5’i o faktöre ilişkin olmalıdır (Çokluk, Şekercioğlu ve Büyüköztürk, 2010; Tavşancıl, 2014). Bu çalışmada açıklanan toplam varyansın \%44.223 olması kabul edilebilir sınırlar arasında olduğunu göstermektedir.

\subsection{Doğrulayıcı Faktör Analizi}

Araştırmanın bu kısmında açımlayıcı faktör analizi sonucunda hazırlanan ölçeğin 2 faktörden ve 17 maddeden oluşan yapısını doğrulamak amacıyla doğrulayıcı faktör analizi yapılmıştır. Doğrulayıcı faktör analizi için açımlayıcı faktör analizinin verilerinden farklı olarak 181 öğretmen adayından veri toplanmıştır. Doğrulayıcı faktör analizine ilişkin diyagram Şekil ı'de yer almaktadır. 


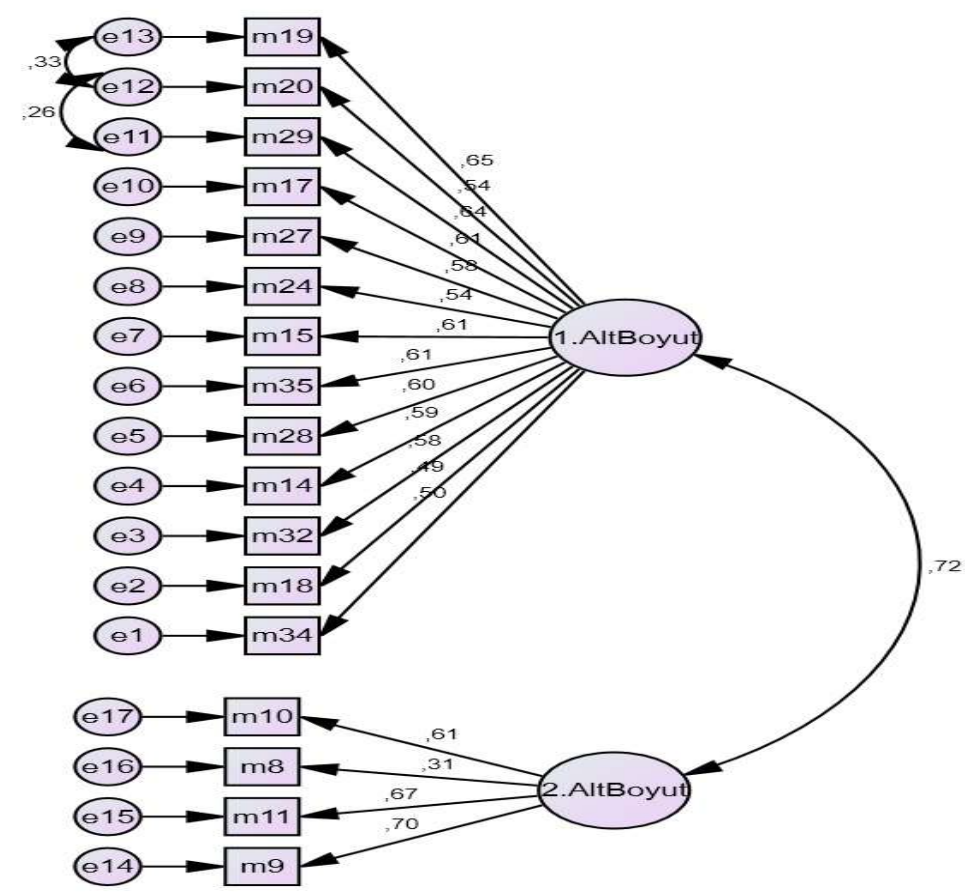

Şekil 1. Ölçeğin faktör yapısına ilişkin doğrulayıcı faktör analizi diyagramı

Ölçeğin faktör yapısının doğrulanmasına yönelik yapılan DFA sonucunda 1. alt boyut altında yer alan maddelerin faktör yüklerinin 0,50 ile 0,65 arasında olduğu, 2. alt boyut altında yer alan maddelerin faktör yüklerinin ise 0,31 ile 0,70 arasında olduğu görülmektedir. Maksimum olasılık tekniği kullanılarak yapılan doğrulayıcı faktör analizi sonucunda uyum indeksleri CMIN/DF $\left(\mathrm{X}^{2} / \mathrm{sd}\right)=1,548$; GFI= ,901; CFI=,927; AGFI=,902; TLI= ,914; RMSEA= ,055 ve SRMR= ,054 olarak hesaplanmıştır. DFA'ya ait uyum indeksleri ve literatürde belirtilen referans aralıkları (Çokluk, Şekercioğlu \& Büyüköztürk, 2010; Erkorkmaz, Etikan, Demir, Özdamar \& Sanisoğlu, 2013; Hooper, Coughan \& Mullen, 2008; Meydan \& Şeşen, 2011; Schermelleh-Engel, Moosbrugger \& Müller, 2003; Yıldırım \& Naktiyok, 2017, s.297) ve araştırmada elde edilen sonuçlar Tablo 4'te yer almaktadır.

Tablo 4. Ölçeğe ilişkin uyum indeksleri

\begin{tabular}{llll}
\hline Uyum İndeksi & Uyum Değeri & Referans Değeri & Yorum \\
\hline CMIN/DF & 1,548 & $0<\chi 2 / \mathrm{sd} \leq 2$ & Mükemmel Uyum \\
TLI &, 914 &, $90<\mathrm{TLI} \leq, 94$ & Kabul Edilebilir Uyum \\
AGFI & .902 &, $85 \leq \mathrm{SRMR} \leq .95$ & Kabul Edilebilir Uyum \\
RMSEA &, 055 &, $05 \leq \mathrm{RMSEA} \leq, 08$ & Kabul Edilebilir Uyum \\
SRMR &, 054 & $0.05 \leq \mathrm{SRMR} \leq .10$ & Mükemmel Uyum \\
CFI &, 927 &, $90<\mathrm{CFI} \leq, 94$ & Kabul Edilebilir Uyum \\
GFI &, 901 &, $90<\mathrm{GFI} \leq, 94$ & Kabul Edilebilir Uyum \\
\hline
\end{tabular}


DFA'da 1. faktörün M19 - M20 numaralı maddeleri ile M20- M29 numaralı maddeler arasında uyum indekslerinin güçlendirilmesi için bir düzenleme yapma ihtiyacı ortaya çıkmış ve gerekli düzenlemeler yapılmıştır. Çocuk edebiyatında şiddet dili farkındalık ölçeğinin uyum indeksleri incelendiğinde, ölçeğin iki faktörlü yapısının referans değerleri karşıladığına işaret etmektedir.

Çocuk edebiyatında şiddet dili farkındalık ölçeğinin 2 faktörlü yapısı doğrulayıcı faktör analizi ile desteklendikten sonra faktörlerin iç tutarlıkları hesaplanmıştır. Güvenirlik katsayıları Tablo 5'te verilmiştir.

Tablo 5. Ölçeğin son şekline ilişkin ortalama, standart sapma ve Cronbach Alpha güvenirlik katsayıları

\begin{tabular}{llll}
\hline Faktör & Ortalama & Standart Sapma & $\alpha$ \\
\hline 1. Faktör & 4,06 &, 58 &, 87 \\
2. Faktör & 3,96 &, 65 &, 71 \\
Toplam & 4,03 &, 54 &, 88 \\
\hline
\end{tabular}

Tablo 5’te ölçeğin son hâline ilişkin Cronbach Alpha değerleri 1. faktör için .87, 2. faktör için $\quad .71$, ve ölçeğin tamamı için .88 olarak bulunmuştur. Bu değerlere dayanarak çocuk edebiyatında şiddet dili farkındalık ölçeğinden elde edilen verilerin oldukça güvenilir olduğu söylenebilir.

Çocuk edebiyatında şiddet dili farkındalık ölçeğinin toplam puanı ile 2 faktörün birbirleri içindeki tek tek korelasyon katsayıları incelenmiş ve sonuçlar Tablo 6'da verilmiştir.

Tablo 6. Ölçeğin Faktörler Arası Korelasyon Değerleri

\begin{tabular}{llll}
\hline Faktör & 1. Faktör & 2. Faktör & Toplam \\
\hline 1. Faktör & - &, $512^{* *}$ &, $970^{* *}$ \\
2. Faktör & - & - &, $705^{* *}$ \\
\hline *** & & &
\end{tabular}

$$
\text { **p }<, 01
$$

Ölçeğin toplam puanı ile iki faktörü arasındaki korelasyon değerlerinin yüksek düzeyde pozitif yönlü olduğu ve bu değerler arasında .01 düzeyinde anlamlı ilişki olduğu sonucuna ulaşılmıştır. Ölçeğin iki faktörü arasındaki korelasyon katsayısının da .512 olduğu ve .01 düzeyinde anlamlı bir ilişki olduğu belirlenmiştir. Elde edilen bu bulgular ölçeği oluşturan faktörlerin uyumlu ve ilişkili olduğunu göstermektedir.

\section{Sonuçlar}

Çocuk edebiyatında şiddet dili farkındalık ölçeği geliştirmek amacıyla yapılan bu araştırmada öncelikle kapsamlı bir alan yazın taraması yapılmış ve uzman görüşleri alınarak madde havuzu hazırlanmıştır. 50 maddeden oluşan madde havuzu çocuk edebiyatı, rehberlik ve psikolojik danışmanlık, psikoloji, Türkçe eğitimi, Türk dili ve edebiyatı eğitimi ve eğitim programları ve öğretim alanında çalışan 10 uzmanın görüşü alınarak gözden geçirilmiş ve ölçek formu 39 maddeden oluşturulmuştur. Maddelerin anlaşılırlı̆̆ını kontrol etmek için 30 öğretmen adayına ölçek maddeleri okunmuş ve onların görüşleri 
doğrultusunda bazı düzeltmeler yapılmıştır. Ayrıca öğretmen adaylarının ölçeğin bütün maddelerini okuyup okumadıklarını tespit edebilmek amacıyla maddelerin arasında "bu maddeyi boş bırakınız." maddesi eklenmiş ve bu maddeye ilişkin görüş belirten 18 öğretmen adayının formu analiz kapsamı dışında tutulmuştur. Ölçeğin geçerliğini test etmek amacıyla öncelikle AFA yapılmıştır. Birinci uygulamada 232 öğretmen adayı çalışma grubunu oluşturmuştur. AFA şartlarının sağlanıp sağlanmadığı KMO ve Barlett Küresellik testleri ile kontrol edilmiş ve şartların sağlandığı sonucuna ulaşılmıştır. AFA'da faktör yükü .3o'un altındaki maddeler ile birden fazla faktör altında faktör yüküne sahip, iki faktör yükü arasında .10 ve daha az fark bulunan binişik maddeler ölçekten çıkarılmıştır. Çıkarılan maddelerden sonra ölçeğin özdeğerleri Monte Carlo paralellik testi ile karşılaştırılmış ve ölçeğin 2 faktörlü yapıdan oluşmasının doğru olacağına karar verilmiştir. Bu analizler sonucunda ölçeğin 2 faktörlü ve 17 maddeden oluştuğu görülmüştür. 17 maddelik ölçek toplam varyansın \%44,223'ünü açıkladığı, 1. faktörün tek başına \%36,557'sini, 2. faktörün tek başına \%7,666'sını açılladığı belirlenmiştir. \%40 ve 60 arasındaki toplam varyans değerinin sosyal bilimlerde yeterli olduğu iddia edildiği ve bir faktörün anlamlı olması için açılanan toplam varyansın en az \%5’inin o faktöre ilişkin olması gerektiği (Çokluk ve diğerleri, 2010; Tavşancıl, 2014) düşünüldüğünde bu değerlerin ölçeğin geçerliği için yeterli olduğu söylenebilir.

AFA'nın ardından 181 kişilik farklı bir örneklem üzerinde toplanan verilere yönelik yapılan DFA sonucunda 1. Alt boyut altında yer alan maddelerin faktör yüklerinin 0,50 ile o,65 arasında olduğu, 2. Alt boyut altında yer alan maddelerin faktör yüklerinin ise 0,31 ile 0,70 arasında olduğu görülmektedir. Maksimum olasılık tekniği kullanılarak yapılan doğrulayıcı faktör analizi sonucunda uyum indeksleri $\mathrm{CMIN} / \mathrm{DF}\left(\mathrm{X}^{2} / \mathrm{sd}\right)=1,548 ; \mathrm{GFI}=, 901 ; \mathrm{CFI}=, 927 ; \mathrm{AGFI}=, 902 ; \mathrm{TLI}=, 914 ; \mathrm{RMSEA}=, 055$ ve $\mathrm{SRMR}=$, 054 olarak hesaplanmıştır. Literatürdeki referans değerleri ile bu değerler karşılaştırıldığında da kabul edilebilir ve iyi uyum gösteren değerler olduğu anlaşılmaktadır.

Ölçeğin son hâline ilişkin hesaplanan Cronbach Alpha değerlerinin 1. faktör için .87, 2. faktör için .71, ve ölçeğin tamamı için .88 olarak bulunması, geliştirilen çocuk edebiyatında şiddet dili farkındalık ölçeğinden elde edilen verilerin oldukça güvenilir olduğu söylenebilir. Ölçeğin toplam puanı ile iki faktörü arasındaki korelasyon değerlerinin yüksek düzeyde pozitif yönlü olduğu ve bu değerler arasında .01 düzeyinde anlamlı ilişki olduğu sonucuna ulaşılmıştır. Ölçeğin iki faktörü arasındaki korelasyon katsayısının da .512 olduğu ve .01 düzeyinde anlamlı bir ilişki olduğu belirlenmiştir. Elde edilen bu bulgular ölçeği oluşturan faktörlerin uyumlu ve ilişkili olduğunu göstermektedir.

Sonuçlar genel olarak değerlendirildiğinde, “Çocuk Edebiyatında Şiddet Dili Farkındalık Ölçeği” nin çocuk edebiyatı alanında kullanılabilecek geçerli ve güvenilir bir ölçme aracı olduğu söylenebilir. Çocuk edebiyatında şiddet dili farkındalık ölçeğinin bu alandaki önemli bir boşluğu doldurması açısından önemli olduğu görülmektedir. Buna karşın bu ölçek bir devlet üniversitesinin eğitim fakültesinde çocuk edebiyatı dersini alan öğretmen adayları ile sınırıdır. Bu nedenle sonuçların genellenebilirliği için farklı örneklem grupları üzerinde ölçeğin geçerliği ve güvenirliğinin test edilmesinin önemli olduğu değerlendirilmektedir.

\section{Kaynaklar}

Aktaş, E., \& Uzuner Yurt, S. (2016). The factors being not "Proper For Child" in the stories of Ömer Seyfettin in terms of children' literature. International Online Journal of Educational Sciences, 9(1), 207-223.

Aytekin, H. (2008). Çocuk edebiyatında ölüm teması. Selçuk Üniversitesi Sosyal Bilimler Enstitüsü Dergisi, 20, 89-102. 
Blatt, G. T. (1972). Violence in children's literature: A content analysis of a select sampling of children's literature and a study of children's responses to literary episodes depicting violence. ERIC Digest, ED072439.

Büyüköztürk, Ş. (2008). Sosyal bilimler için veri analizi el kitabı. Ankara: Pegem Akademi.

Cathell, R. B., \& Baggaley, A. R. (1960). The salient variable similarity index for factor matching. British Journal of Statistic in Psychology, 14(13), 33-46.

Çakır, P. (2013). Türkçe ders kitaplarındaki öykülerin çocuğa görelik açısından incelenmesi. Turkish Studies, 8(1), 1171-1180.

Çokluk, Ö., Şekercioğlu, G. ve Büyüköztürk, Ş. (2010). Sosyal bilimler için çok değişkenli istatistik. Ankara: Pegem Akademi.

Dağlıŏ̆lu, H. E., \& Çamlıbel Çakmak, Ö. (2009). Okul öncesi çocuklarına yönelik yayınlanan hikâye kitaplarının şiddet ve korku öğeleri açısından incelenmesi. Türk Kütüphaneciliği, 23(3), 510-534.

Dilidüzgün S. (2004). Okuma öğretimi hedefleri bağlamında Türkçe ders kitaplarındaki çocuk edebiyatı ürünleri. Hasan Ali Yücel Eğitim Fakültesi Dergisi, 2, 43-55.

Dursunoğlu, H. (2015). Çocuk edebiyatı. (Ed.: Ö. Yılar \& L. Turan). Eğitim fakülteleri için çocuk edebiyatı içinde. (3. baskı, ss. 27-36). Ankara: Pegem Akademi.

Erkorkmaz, Ü., Etikan, İ., Demir, O., Özdamar, K., \& Sanisoğlu, S. Y. (2013). Doğrulayıcı faktör analizi ve uyum indeksleri. Türkiye Klinikleri J Med Sci, 33(1), 210-223.

Field, A. (2009). Discovering statistics using SPSS ( $3^{\text {rd }}$ ed.). London: Sage Publications.

Gönen, M., Ertürk, G., \& Özen Altınkaynak, Ş. (2011). Examining the preschool teachers' use of different approaches in children's literature. Procedia -Social and Behavioral Sciences, 15, 4098-4104.

Hooper, D., Coughan, J., \& Mullen, M. R. (2008). Structural equation modelling: guidelines for determining model fit. Electronic Journal of Business Research Methods, 6(1), 53-60.

Hökelekli, H. (2007). Çocuk ve gençlerde şiddet olgusu ve önlenmesine yönelik öneriler. Değerler Ĕ̈itimi Dergisi, 5(14), 61-78.

Kanter, B. (2014). Çocuk ve ilk gençlik edebiyatında eleştirel bakış. Türk Dili Dergisi, Çocuk ve İlk Gençlik Edebiyatı Özel Sayısı, 256.

Kara, Ş. (2007). Fantastik çocuk kitaplarında uzamın imgesel işlevi ve şiddet. Çankaya University, Journal of Arts and Sciences, 7, 61-72.

Karagöz, B. (2017). Türkçe öğretmeni adaylarının çocuk ve gençlik edebiyatı yapıtlarının temel özelliklerini bilme yeterlikleri. Turkish Studies, 12(14), 211-230.

Karataş, E. (2014). Çocuk edebiyatında 'karakter' kavramı. Muğla Sitkı Koçman Üniversitesi Sosyal Bilimler Enstitüsü Dergisi, 33, 60-79.

Kline, R. B. (2005). Principles and practice of structural equation modelling (2nd ed.). New York: Guilford Press

Kline, P. (1994). An easy guide to factor analysis. New York: Routledge.

Lelli, C. M. (2010). Incorporating Domestic Violence Awareness Through an Undergraduate Reading Course Focused on Children's Literature. Online Submission, Ed.D. Dissertation, Widener University.

Lüle Mert, E. (2016). Çocuk edebiyatı eleştirisinin Türkçe öğretmen adaylarının çocuk kitaplarını gelişim düzeylerine göre ayrıştırma becerisine etkisi. Erzincan Üniversitesi Eğitim Fakültesi Dergisi, 18 (2), 1252-1274.

Meydan, C. H., \& Şeşen, H. (2011). Yapısal eşitlik modellemesi Amos uygulamaları. İstanbul: Detay.

Neale, M. N., \& Liebert, R. M. (1980). Science and Behavior: an Introduction to Methods of Research. London: Prentice Hall International, Inc. 
“Violence Language” Awareness Scale in Children's Literature: Validity and Reliability Study / L. Turan, F. Gerez Taşgın (p. 232248)

Neydim, N. (2014). Çocuk edebiyatını kavramak ve öğretmek. Türk Dili Dergisi, Çocuk ve İlk Gençlik Edebiyat Ozel Sayısı, 294.

Nimon, M. (1993). Violence in children's literature today. dreams and dynamics. Retrived on 02.05.2018 from http://files.eric.ed.gov/fulltext/ED399935.pdf.

Oğuzkan, A. F. (2010). Çocuk Edebiyatı. Ankara: Anı.

Pallant, J. (2017). SPSS kullanma kılavuzu-SPSS ile adım adım veri analizi. (Çev. Sibel Balcı, Berat Ahi). Ankara: Anı.

Schermelleh-Engel, K., Moosbrugger, H., \& Müller, H. (2003). Evaluating the fit of structural equation models: tests of significance and descriptive goodness-of-fit measures. Methods of Psychological Research Online, 8(2), 23-74.

Seçer, İ. (2015). Psikolojik test geliştirme ve uyarlama süreci SPSS ve LISREL uygulamaları. Ankara: Anı.

Sever, S. (2002). Çocuk kitaplarına yansıtılan şiddet. Ankara Üniversitesi Eğitim Fakültesi Dergisi, 35(1-2), 25-37.

Sever, S. (2003). Çocuk ve edebiyat. Ankara: Kök.

Sever, S. (2007). Çocuk edebiyatı öğretimi nasıl olmahıdır? II. Ulusal Çocuk ve Gençlik Edebiyatı Sempozyumu (Yay. Haz.: S. Sever), ss. 41- 56. Ankara: Ankara Üniversitesi Basımevi.

Şahin, A. (2015). Çocuk-edebiyat ve çocuk edebiyatı. (Ed. Ö. Yılar \& L. Turan). Eğitim fakülteleri için çocuk edebiyat içinde (ss. 1-36). Ankara: Pegem Akademi.

Şen, E. (2016). Çocuk edebiyatında bir yaşam gerçekliği olarak ölüm olgusu üzerine bir inceleme (Sevim Ak Örneği). Uluslararası Türk Kültür Coğrafyasında Sosyal Bilimler Dergisi, 1(1), 14-23.

Şimşek, T. (2014). Çocuk edebiyatı tarihine ön söz. Türk Dili Dergisi, 7, 756, 15-58.

Şirin, M. R. (2007). Çocuk edebiyatına eleştirel bir bakış. Ankara: Kök.

Tabachnick, B. G., \& Fidell, L. S. (2015). Çok değişkenli istatistiklerin kullanımı (6. Baskıdan çeviri) (M. Baloğlu, Çev. Ed.). Ankara: Nobel. (Çalışmanın orijinali 2013 yılında basılmıştır).

Tavşancıl, E. (2014). Tutumların ölçülmesi ve SPSS ile veri analizi. (5. baskı). Ankara: Nobel.

Tekin, H. (2005). Çocuk edebiyatında şiddet korku ve sevgi üçgeni. Hece Edebiyat Dergisi, 104-105, 304-306.

Temizkan, M. (2011). Türkçe öğretmeni adaylarının çocuk kitaplarında bulunması gereken özellikleri algılama durumları. Gazi Eğitim Fakültesi Dergisi, 31(2), 339-357.

Temizyürek, F. (2014). Çocuk edebiyatı öğretimi üzerine. Türk Dili Dergisi, Çocuk ve İlk Gençlik Edebiyatı Özel Sayısı, 301.

Turan, L. (2015). Çocuk yayınlarında yer alan bazı olumsuzluklar. (Ed. Ö. Yılar ve L. Turan). Eğitim Fakülteleri Iç̧in Çocuk Edebiyatı içinde (ss. 203-223). Ankara: Pegem Akademi.

Turan, L. (2006). Violence and death in stories of war period writer Ömer Seyfettin. Online Submission, Retrived from http://files.eric.ed.gov/fulltext/ED493901.pdf at 04.05.2016.

Uluğ, E., \& Bayraktar, A. (2014). Determination of the required features of children's picture books. Journal of Education and Future, 6, 25-42.

Watkins, M. W. (2000). Monte carlo PCA for parallel analysis - Computer software. State College, PA: Ed \& Psych Associates.

Ylldırım, F. \& Naktiyok, S. (2017). The mediating role of organizational support in the effect of transformational leadership on employee empowerment. Polish Journal of Management Studies, 16(1), 292-303. 